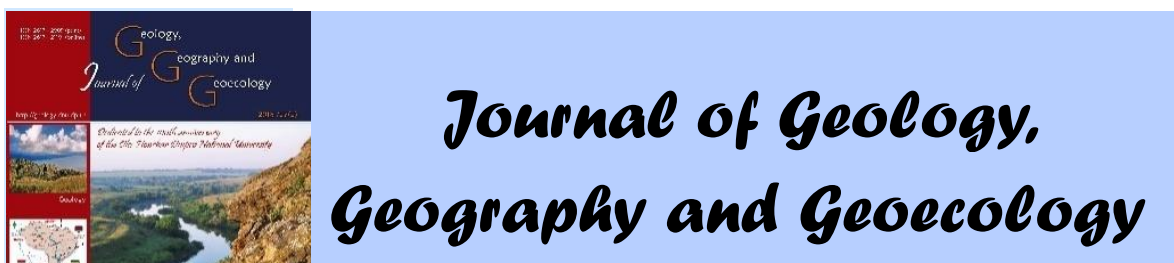

Journal home page: geology-dnu-dp.ua

\title{
Microaggregate composition and other features of the loesses of Kryvyi Rih
}

\author{
T.P. Mokritskaya \\ Oles Gonchar Dnipro National University, Dnipro, Ukraine, e-mail: mokritska@i.ua
}

Received 03.02.2019;

Received in revised form 20.02.2019;

Accepted 15.03.2019

pores in various soil media, cavities of various origin and cracks are based on the theory of fractals. Techniques for a practical application of the theory to estimating the scope of work, calculating the indicators, and engineering-geological forecasting are being developed. The previous studies showed that the theory of fractals, applied to the investigation of subsidence degradation, allowed an assessment of deformations arising from the decomposition of microaggregates in loess deposits of the city of Dnipro. A long period analysis of changes in the properties of loess deposits on the territory of the city of Kryvyi Rih showed that the changes in physical properties and conditions had a regional character. The paper presents the results of experimental studies of the microaggregate composition of loess samples taken in the depth interval of $1-7 \mathrm{~m}$ in the zone of influence of Kryvyi Rih. The microaggregate composition was determined by the new method, which we tested while studying the loess of the city of Dnipro. The total number of particle size analyses performed was 128 . The results of the analyses were used to estimate the fractal dimension of the function of particle distribution by volume. The values of the function vary slightly, but the nature of the changes differs depending on the method of sample preparation for the analysis and its dispersity. Strength indexes have been determined with Physical. It has been shown that there is a correlation between the content of fine particles and the values of limiting tangential stresses Indicators of the physical condition are the repressors of tangential stress values. According to the results of the correlation analysis, the values of the soil density, the upper and lower limits of plasticity, and the content of particles with a size of 0.05-0.001 mm and less than 0.001 $\mathrm{mm}$ were selected as repressors.

Keywords: loess, fractal, granulometric composition, Kryvyi Rih.

\section{Мікроагрегатний склад та інші особливості лесів Кривого Рогу}

\section{Т.П. Мокрицька}

Дніпровський наџіональний університет імені Олеся Гончара, Дніпро, Україна, е-таil: mokritska@i.ua 
Ключові слова: лес, фрактал, гранулометричний склад, Кривий Ріг.

Introduction. Loess deposits are widespread on the territory of the city of Kryvyi Rih. The process of technogenesis has given rise to changes in their properties and state (Mokritskaya, 2013). Monitoring geological processes is a pressing scientific problem (Skrzypczak I. et al., 2017). Changes in the properties of subsiding and other dispersed soils are accompanied by a change in the microaggregate composition and by the formation of a new structure, accompanied by the formation of a soil with new properties. The concept of soils as a medium similar to a natural fractal is widespread. A significant contribution to the study of structures of discrete soil media and the patterns of fractal distribution of pores and particles was made by A. R. Russel (2010-2014). Various aspects of the application of the fractal theory to loess were investigated in the works of Delage P. et al., 2005, Du Y C et al., 2017.

Y. Yamakawa et al., 2017, proved the formation of diffuse bifurcations, i.e. a catalyst that produces different structures of shear bands. Dafflon, B., and W. Barrash, 2012, showed that the estimation of porosity spatial distribution is a topical scientific issue that can be solved by modeling the structure using simulation methods. M. J. Jiang and al., 2017, showed that the form of soil degradation strongly depends on the joint geometry, i.e. the structure of the soil. They also showed that the bond breaking due to stretching is the dominant factor. Investigating the deformation behavior of natural loess in the vicinity of the tunnel, M.J. Jiang and al., 2017, showed that the stress - strain increment ratio changes depending on different pressure directions. These findings also testify to the importance of studying the natural structure of loess. W.-C. Cheng and al., 2017, showed that the parameters of karst forms (diameter and length) are described by a power dependence; they used self-similarity and invariance to calculate the volume of cementation of cavities. A. Sufian, A. R. Russed, A. J. Whittle, 2017, showed that the anisotropy of pores can be associated with the anisotropy of contacts between particles. Gao, Y. and al., 2018, showed that in swelling, intraaggregate porosity is more important than interaggregate one. K. Ran and al., 2018, showed that changes in the physical structure have a greater impact on the mechanical properties of the loess than a change in the chemical component. X. Zhang and al., 2017, experimentally and theoretically proved that the porous soil medium with a multifractal distribution of particles is characterized by a "memory" even under heavy loads. A review of publications, an analysis of the results of previous studies shows that the analysis of the microstructure of loess soils in the territory of Kryvyi Rih is a pressing issue.

Materials and methods. The natural-technogenic system under study is located within the boundaries of a polygenetic plain with several hypsometric levels. Archean plagiogranites of the Dniprovsky and Saksagansky complexes and Lower Proterozoic (Kryvorizka and InguloIngulenska series) rocks take part in the geological structure of the territory; the development of the areal type crust of weathering is associated with the Proterozoic.

Eopleistocene, Neogene and Paleogene sediments are represented mainly by clay. The Neopleistocene includes Upper Pleistocene alluvial sands, as well as eluvial and aeolian loesslike deposits (Prychornomorsky, Dofinivsky, Bugsky, Priluksky horizons); the lower and middle Pleistocene is represented by subaerial loess-like formations of the Kaidaksky, Dniprovsky, Zavadsky horizons. The thickness of the subaerial covers reaches 7-13 m. The Kryvyi Rig iron ore basin is located within the hydrogeological province of the Ukrainian Shield and the southern slope of the Prychornomorsky artesian basin. The depth of groundwater is subordinated to geomorphological zonality, varying from 1.0 to $5.0 \mathrm{~m}$ and more. The rate of current positive vertical movements is $0.6-4.8$ $\mathrm{mm} /$ year, horizontal $-3-10 \mathrm{~mm} /$ year.

On the whole, the geotechnical conditions of the region are complex. The low thickness of the periglacial formation and the wide distribution of thick layers of clay in its base contribute to the limitation of the zone of technogenic influences. Nevertheless, the long period analysis of its state allows revealing the features of the changes that have occurred.

Within the boundaries of the natural technogenic system of a regional level, including the Kryvyi Rih iron ore basin, the main sources of technogenic impacts are mining companies, urban areas and agricultural areas. In the assessment of the intensity of anthropogenic impacts by indirect criteria (urban population, depth of mine workings and the area of disturbed soil, KP Ukryuzgeologiya), the following stages were distinguished for the period from 1949 to 2006: 1949-1955. (I); 1956-1971 (II); 1972-1989 (III); 1990-2019 (IV). Regionally manifested processes of subsidence have been developing; waterlogging, the rise of groundwater levels in the areas of intensive construction has continued; by 
2008 , the population and water consumption had decreased. The intense technogenic impact has affected the state of the periglacial formation represented by vulnerable subaerial loess-like and paleo-soil formations. Today, identifying regional changes in the soil properties of the soil-loess series of the periglacial formation is an urgent scientific issue.

To assess the regional changes, the study uses the results of engineering and geological investigations, which have been included in the regional UkrYuzhegeologiya database, as well as the findings obtained by DniproGiprotrans and GP DneproGIINTIZ. The total number of samples exceeds 1000. The information is provided on the engineering-geological properties of loess-like loams of the periglacial formation and other stratigraphic-genetic complexes, which occur within the boundaries of industrial sites of enterprises and residential construction in the territory of Kryvyi Rih and areas of agricultural activity. The data were processed for the periods corresponding to the stages of the intensive technogenic impacts: 1949-1971. (Stages I and II combined), 1972-1989 (III) and 1990-2006 (IV). An analysis of the statistical features of the distribution of the properties of the unsplit Prychornomorsky-Dofinivsky horizon in time within the boundaries of the city of Kryvyi Rih indicates a decrease in the variability of physical properties, relative subsidence, and an increase in the non-uniformity of mechanical properties during 1972-1989 and 1990-2006 (stages II and III under study); the state of the horizon by its ability to perform geo-ecological functions was deteriorating. The following regional trends in the changes of soils of the periglacial formation in the zone of influence of the Kryvyi Rih agglomeration were established:
- indicators of soil condition are relative subsidence, specific cohesion, modulus of deformation;

- subaerial loess loams are most sensitive;

- degradation of the subsidence properties of soils leads to a change in indicators that depend on the degree of disturbance of their structural and textural characteristics during long-term changes in physical properties;

- degradation of soil subsidence in this region is accompanied by a decrease in their specific adhesion and deformation modulus with a simultaneous increase in the values of the internal friction angle;

- values of the mechanical properties of soils in the region correlate with the values of their porosity and density more closely than with their humidity;

- the relationship between the porosity and natural moisture content of loess-like loams in the degradation of their subsidence properties is not linear in time;

- the direction of changes in the mechanical properties of the Prychornomorsky-Dofinivsky horizon coincides with the zone and stage of the same anthropogenic impacts. The increases in variability and asymmetry and deterioration of mechanical properties have a regional character.

This paper presents the results of the study of the microaggregate composition of loess deposits sampled by the enterprise ZAT Dniprokomunproekt in 2018 and submitted for scientific analyses to the research group of the Institute of Geology at the Oles Gonchar DNU. The sampling points are shown in Fig. 1. Samples of the Prychornomorsky-Dofinivsky horizon were studied; sampling depths was from 1 to $7 \mathrm{~m}$.

Fig. 1. Location of the sampling points on the profile (city of Kryvyi Rih). 
Results and discussion. The laboratory studies enabled obtaining the indicators of physical and classification properties of the soil. According to the findings, the samples mainly represent light loams of dry and stiff-plastic consistency (Table 1). Laboratory studies of the strength of loess loams were also performed as single shear tests.

The main objective of the study was to determine the microaggregate and granulometric composition of loess-like loams using a new technique (Ryashchenko, 2010). In accordance with this technique, the determination of microaggregate and granulometric composition of a soil is carried out with three different methods of preparation: aggregate, semi-dispersion and dispersion methods. In the aggregate method, the pre-soaked sample is subjected to mechanical shaking. With the semi-dispersion method, the sample is boiled with an addition of an aqueous solution of ammonia, and with the dispersion method, the sample is boiled with an addition of sodium pyrophosphate. Different methods of preparation affect the dispersity of the soil.

The difference in estimates of the number of particles of a certain size shows the importance of the microaggregate composition of the soil as an indicator of its state. The difference in the estimates characterizes the possible region of states by the dispersity of the soil subjected to mechanical or chemical action.

Table 1. Indicators of the physical properties of Upper Quaternary loess-like loams (Kryvyi Rih, 2018).

\begin{tabular}{|l|l|l|l|l|l|l|}
\hline $\begin{array}{l}\mathrm{N} \\
\mathrm{o}\end{array}$ & $\begin{array}{l}\text { Depth of } \\
\text { sampling, } \\
\mathrm{m}\end{array}$ & \begin{tabular}{l} 
Physical properties \\
\cline { 3 - 7 }
\end{tabular} & $\begin{array}{l}\text { Natural } \\
\text { moisture } \\
\text { content, unit } \\
\text { fraction (W) }\end{array}$ & $\begin{array}{l}\text { Moisture content } \\
\text { at the yield point, } \\
\text { unit fraction } \\
\left(\mathrm{W}_{\mathrm{L}}\right)\end{array}$ & $\begin{array}{l}\text { Moisture content at the } \\
\text { rolling-up boundary, } \\
\text { unit fraction } \\
(\mathrm{Wp})\end{array}$ & $\begin{array}{l}\text { The density of } \\
\text { soil particles, } \\
\mathrm{g} / \mathrm{cm} 3 \\
\left(\rho_{\mathrm{s}}\right)\end{array}$ \\
\hline 1 & 1 & 0,22 & 0,36 & 0,2 & 2,68 & $\begin{array}{l}\text { Soil } \\
\text { density, } \\
\mathrm{g} / \text { cm3 } \\
(\rho)\end{array}$ \\
\hline 2 & 7 & 0,21 & 0,32 & 0,18 & 2,68 & 1,86 \\
\hline 3 & 3 & 0,19 & 0,33 & 0,21 & 2,67 & 1,81 \\
\hline 4 & 1,5 & 0,2 & 0,32 & 0,19 & 2,67 & 1,76 \\
\hline 5 & 1,5 & 0,18 & 0,34 & 0,24 & 2,67 & 1,87 \\
\hline 6 & 3 & 0,19 & 0,31 & 0,18 & 2,67 & 1,76 \\
\hline 7 & 6,8 & 0,19 & 0,29 & 0,19 & 2,67 & 1,76 \\
\hline 8 & 6,6 & 0,15 & 0,26 & 0,18 & 2,67 & 1,71 \\
\hline
\end{tabular}

In the previous studies of the properties of subsiding soils of the Middle Dnieper region, we showed (Mokritskaya, 2013) that loess soils are characterized by a change in the microaggregate composition under prolonged filtration and compaction. It was also shown that the results of particle size analysis may be used to calculate the values of the function of the fractal dimension of particles by mass, and to find the predicted values of the volume deformation for a new state of soil that evolves after the break-up of microaggregates. The behavior of loess-like upper quaternary loams in the zone of influence of Kryvyi Rih also shows a predisposition to changes in dispersity under various types of technogenic impacts.

A total of 128 assessments of the granulometric composition of loess loams were made. The contents of the following particle sizes were determined: larger than $1 \mathrm{~mm}, 1-0.5 \mathrm{~mm}$, 0.5-0.25 mm, 0.1-0.25 mm, 0.05-0.1 mm, 0.01$0.05 \mathrm{~mm}, 0.005-0.01 \mathrm{~mm}, 0.005-0.001 \mathrm{~mm}$ and less than $0.001 \mathrm{~m}$. Typical particle size distribution curves of loess prepared by different methods are shown in Fig. 2 - 4.

In the aggregate and semi-dispersion methods of preparation, the maximum content of particles of fractions $0.05-0.25 \mathrm{~mm}$ and $0.25-0.5$ $\mathrm{mm}$ is observed, water-sensitive aggregates are mainly destroyed. With the dispersion method of preparation, the content of particles with a size of less than $0.001 \mathrm{~mm}$, as well as fractions with sizes of $0.001-0.002 \mathrm{~mm}, 0.002-0.005 \mathrm{~mm}, 0.005-$ $0.01 \mathrm{~mm}$ increases. An analysis of the curves also shows that the maximum number of fine particles is observed under the dispersion method of preparation, while the minimum number is observed under the aggregate method The semidispersion method of sample preparation results in the changes in the dust particle content. The same patterns were revealed when analyzing the results of the particle-size analysis of loess in the Prydniprovskyi industrial region (Mokritskaya, 2013).

To estimate the values of the particle mass distribution function, we plotted the dependence of the total particle content against the size on a 
double logarithmic scale. Then, the parameters of the linear trend were calculated, and the angular coefficient was used to estimate the values of the particle mass distribution function (Fig. 5). The reliability of estimating the values of the function using the linear trend equation is confirmed by sufficiently high values of the coefficient of determination, since they take values greater than 0.7 .

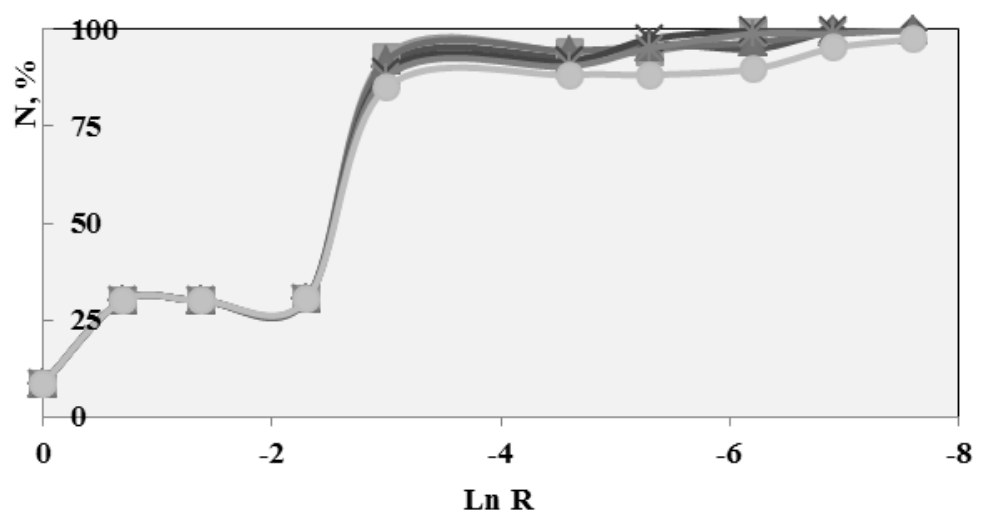

Fig. 2. The results of six simultaneous determinations of the granulometric composition of a sample prepared by the aggregate method.

Notes:

$\mathrm{N}, \%$ - total number of particles;

$\mathrm{R}$ - particle size/

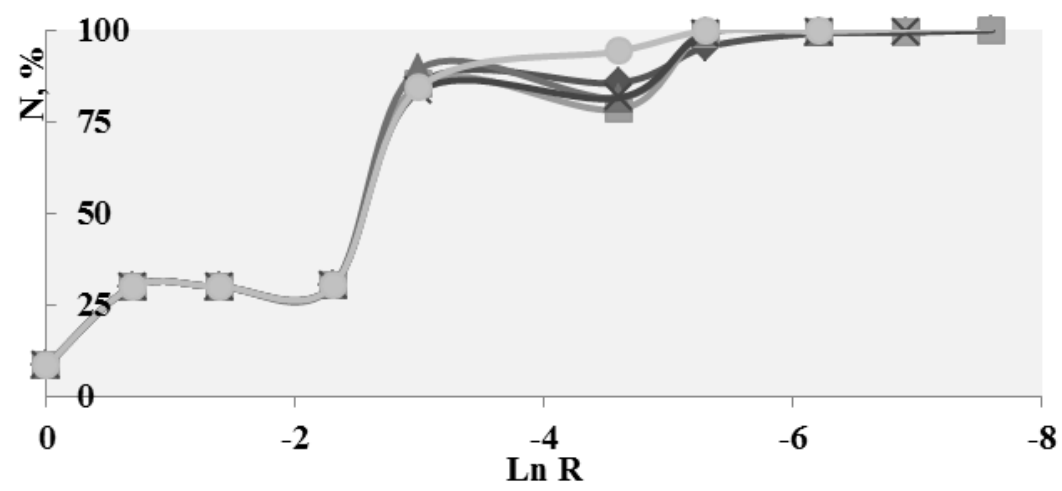

Fig. 3. The results of six simultaneous determinations of the granulometric composition of a sample prepared by the semi-dispersion method.

Notes:

$\mathrm{N}, \%$ - total number of particles;

$\mathrm{R}$ - particle size/

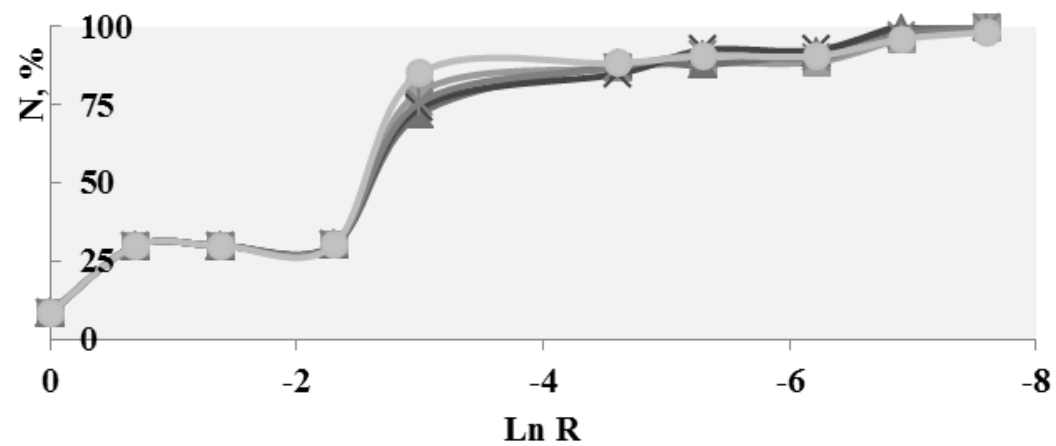

Fig. 4. The results of six simultaneous determinations of the granulometric composition of a sample prepared by the dispersion method.

All the graphs are characterized by a stepped structure, which indicates the prevalence of particles of two classes, i.e. dust and clay in the soil composition. Calculations of the function values were performed for the entire particle size range, which does not underestimate analyzing the contents of individual fractions and their changes. 


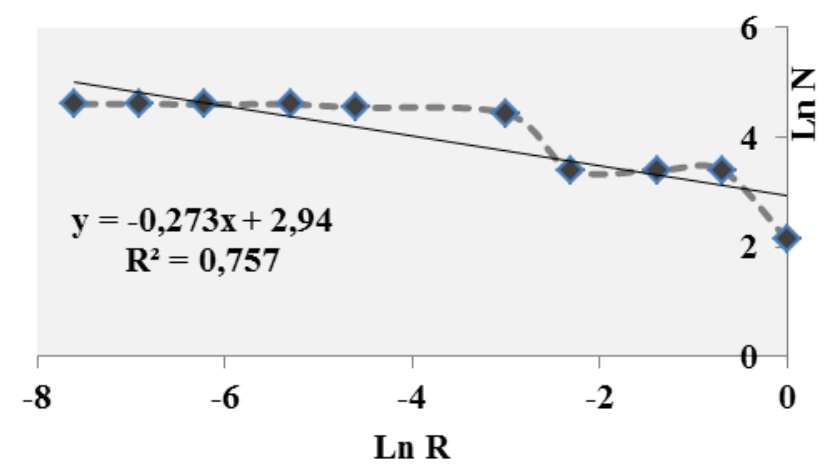

Fig. 5. The total content of particles plotted against their size.

Notes:

1. $\mathrm{R}^{2}$ - coefficient of determination:

2. $(y=-0,273 x+2,94)-$ trend equation.

The calculated values of the fractal dimension of the particle mass distribution function change only slightly (Table 2). The variability of values of

samples taken from larger depths is lower in the case of the semi-dispersion method of sample preparation.

Table 2. Values of the fractal distribution function of particles by mass D.

\begin{tabular}{|c|c|c|c|}
\hline $\begin{array}{c}\text { Depth of } \\
\text { sampling } \\
\mathbf{z}, \mathbf{m}\end{array}$ & $\begin{array}{c}\text { Values of the fractal dimension of the particle mass distribution function for different } \\
\text { methods of sample preparation prior to a particle size analysis }\end{array}$ \\
\cline { 2 - 4 } & $\begin{array}{c}\text { Aggregate method of } \\
\text { preparation } \\
\text { A }\end{array}$ & $\begin{array}{c}\text { Semi-dispersion method of } \\
\text { preparation } \\
\text { S }\end{array}$ & $\begin{array}{c}\text { Dispersion method of } \\
\text { preparation } \\
\text { D }\end{array}$ \\
\hline 1,5 & 2,858 & 2,861 & 2,855 \\
\hline 7 & 2,910 & 2,687 & 2,908 \\
\hline 1 & 2,849 & 2,898 & 2,849 \\
\hline 3 & 2,732 & 2,719 & 2,731 \\
\hline 6,8 & 2,814 & 2,809 & 2,873 \\
\hline 1,5 & 2,787 & 2,795 & 2,848 \\
\hline
\end{tabular}

In order to assess the impact of dispersity and microaggregate composition of loess soils, a statistical analysis of the content of individual fractions, strength parameters and indicators of physical properties was performed. The results were analyzed using the Trial-version of the program STATISTICA. The purpose of the analysis was to trace in what way the dependent variable, i.e. the shear stress of the shear $\tau, \mathrm{MPa}$, is affected by the values of the physical properties and dispersity. According to the results of the correlation analysis, the values of the soil density, the upper and lower limits of plasticity, and the content of particles with a size of $0.05-0.001 \mathrm{~mm}$ and less than $0.001 \mathrm{~mm}$ were selected as regressors. Paired regression equations were obtained (Table 3 ).

Table 3. Models of regression between the values of shear stress for different normal stresses and soil physical properties.

Key to Table 3:

\begin{tabular}{|l|l|l|}
\hline Form of equation & Coefficients of determination & Standard error \\
\hline$\sigma_{0,1}=-3,56+30,87 * \mathrm{Wp}-1,689 * \mathrm{Pl}$ & 0,984 & 0,09 \\
\hline$\sigma_{0,2}=2,02-2 * \mathrm{Wp}-0,727 * \mathrm{Pl}$ & 0,757 & 0,026 \\
\hline$\sigma_{0,3}=2,02-1,96 * \mathrm{Wp}-0,732 * \mathrm{Pl}$ & 0,749 & 0,027 \\
\hline
\end{tabular}

$w_{p}$ - moisture content on the rolling-up border, unit fraction.

$\mathrm{Pl} \mathrm{-} \mathrm{-} \mathrm{density} \mathrm{of} \mathrm{the} \mathrm{soil} \mathrm{of} \mathrm{a} \mathrm{natural} \mathrm{structure,} \mathrm{g} / \mathrm{cm} 3$;

$\sigma_{0.1}-$ - tangential shear stress at a normal stress of $0.1 \mathrm{MPa}$.

Conclusions. The obtained contents of various fractions, which are subject to changes due to mechanical and chemical effects on the soil, suggest the following conclusions: 
- the method of preparation of a loess soil sample affects the content of fine and dust fractions in the zone of influence of the Kryvyi Rih natural-technogenic system;

- processing the results of particle size analysis, performed by the method (Ryashchenko, 2010), allows calculating the values of the fractal mass distribution function of particles;

- the content of the fine fraction has less effect on the strength values of loess soil than physical indicators;

- the nature of the variability of fractal dimension values changes with depth.

Acknowledgements. This work was supported by the Ministry of Education and Science of Ukraine, state budget issue № 0117U001210.

\section{References}

W.-C. Cheng, Q.-L. Cui1, J. S.-L. Shen, A. Arulrajah and D.-J. Yuan. 2017. Fractal Prediction of Grouting Volume for Treating Karst Caverns along a Shield Tunneling Alignment. Appl. Sci., 7, 652; https://doi.org /10.3390/app7070652

Dafflon, B., and W. Barrash, 2012. Three-dimensional stochastic estimation of porosity distribution: Benefits of using ground-penetrating radar velocity tomograms in simulated-annealingbased or Bayesian sequential simulation approaches, Wat. Res. Res., 48, W05553, https://doi.org/10.1029/2011WR010916.

Delage P., Cui Y.J. and Antoine P. (2005) Geotechnical Problems related with Loess deposits in Northern France. Proceedings of International Conference on Problematic Soils, 25-27 May 2005,Eastern Mediterranean University, Famagusta, N. Cyprus. pp. 517-540.

Du Y C, J C Han, S W Zhang, Y F Huang, H Y Wang, L T Luo and W H Zhang (2017) Multidimensional analysis of particle size fractal characteristics in a farmland soil profile IOP Conf. Ser.: Earth Environ. 52 (2017) 012053 Doi:10.1088/1755-1315/52/1/012053

Gao, Y., Sun, D. \& Wu, Y. Bull Eng Geol Environ, 2018. 77: 837. https://doi.org/10.1007/s10064017-1142-0

M. Jiang; J. Sima; Y. Cui; H. Hu; C. Zhou; H. Lei, 2017. Experimental Investigation of the Deformation Characteristics of Natural Loess under the Stress Paths in Shield Tunnel Excavation Int. J. Geomech., 17(9): 04017079 DOI: 10.1061/(ASCE)GM.1943-5622.0000972

M.J. Jiang et al., 2017. DEM analysis of the effect of joint geometry on the shear behavior of rocks. R. S Mechanique, 345 (11), 779-796. https://doi.org/10.1016/j.crme.2017.07.004

Kong R., Zhang F., Wang G., Peng, J., 2018. Stabilization of Loess Using Nano-
SiO2. Materials 11

(6).

1014. https://dx.doi.org/10.3390\%2Fma11061014

Mokritskaya T.P. 2013. Izmenchivost' svoystv periglyatsial'noy formatsii $\mathrm{v}$ rayonakh gornoy promyshlennosti na primere Krivorozhskogo zhelezorudnogo basseyna (Ukraina) [Variability of the properties of the periglacial formation in the areas of the mining industry on the example of the Krivoy Rog iron ore basin (Ukraine)].Vestnik IrGTU, 5, 65 - 72 (in Russian).

Mokritska T., 2013. Peculiarities of degradation in loess soils' deformation and strength properties on the example of Dnipropetrovsk city. Visnyk Taras Shevchenko National University of Kyiv, Geology, 62 (3), 66-70.

Mokritskaya, T.P., Tushev, A.V., Samoylich, K.A. et al. Bull Eng Geol Environ (2018). https://doi.org/10.1007/s10064-018-1361-z

A.R. Russell. 2010. Water retention characteristics of soils with double porosity. European Journal of Soil Science, 61, 412-424. doi: 10.1111/j.13652389.2010.01237.x

Russell A. R. (2011). A compression line for soils with evolving particle and pore size distributions due to particle crushing. Geotechnique Letters 1:59.

Russell, A. R. (2014). How water retention in fractal soils depends on particle and pore sizes, shapes, volumes and surface areas. Ge'otechnique 64 (5):379-390.

Russell A. R., O.Buzzi. (2012) A fractal basis for soilwater characteristics curves with hydraulic hysteresis. Ge'otechnique. 62 (3):269-274.

Ryaschenko T.G. (2010). Regional'noye gruntovedeniye (Vostochnaya Sibir'). [Regional soil science (Eastern Siberia)]. SD RAS, Irkutsk (in Russian).

Skrzypczak I., Kogut J., Kokoszka W., Zientek D. Monitoring of landslide areas with the use of contemporary methods of measuring and mapping. Civil and Environmental Engineering Reports, CEER 2017; 1 (24), 69-82; DOI: 10.1515/ceer-2017-0005.

A. Sufian, A. R. Russe1, A. J. Whittle, 2017. Microscale anisotropy of contacts and pores in granular media. EPJ Web of Conferences, 140, 15003 10.1051/epjconf/201714015003.

Y. Yamakawa, K. Ikeda, I. Saiki, J. D. Reiko, J. Tanaka, 2018. Diffuse bifurcations engraving diverse shear bands in granular materials. Numerical and analytical Methods in Geomachanics, $42 \quad$ (1), 3-33. !)https://doi.org/10.1002/nag.2711

X. Zhang, B. A. Baudet, Wei Hu, Qiang Xu, Characterization of the ultimate particle size distribution of uniform and gap-graded soils, Soils and Foundations, Vol.57, Is.4, 2017, Pages 603-618, https://doi.org/10.1016/j.sandf.2017.04.002. 